\title{
Penerapan Strategi Please ( Pick, List, Evaluate, Activate, Supply, End) Berbantuan Metode Outdoor activity Untuk Meningkatkan Kemampuan Menulis Teks Deskripsi
}

\author{
Dian Sasmi Wulandari $1, *$, \\ ${ }^{1}$ Jurusan Pendidikan Bahasa Inggris Universitas Pendidikan Ganesha, Singaraja Indonesia
}

\begin{abstract}
Abstrak
Penelitian ini bertujuan untuk (1) mengetahui peningkatan keterampilan menulis teks deskripsi siswa kelas VIII A1 SMP Negeri 1 Singaraja dengan strategi PLEASE berbantuan metode outdoor activity, (2) mengetahui langkahlangkah penerapan strategi PLEASE berbantuan metode outdoor activity dalam meningkatkan keterampilan menulis teks deskripsi siswa VIII A1 SMP Negeri 1 Singaraja, dan (3) mengetahui respons siswa kelas VIII A1 SMP Negeri 1 Singaraja terhadap penerapan strategi PLEASE berbantuan metode outdoor activity dalam meningkatkan keterampilan menulis teks deskripsi. Penelitian ini adalah penelitian tindakan kelas yang dilaksanakan dalam satu siklus, yang terdiri dari rencana tindakan, pelaksanaan tindakan, observasi atau evaluasi dan refleksi. Subjek penelitian ini adalah siswa kelas VIII A 1 SMP Negeri 1 Singaraja, berjumlah 30 orang dengan rincian 9 orang putra dan 21 orang putri. Data dianalisis menggunakan statistik deskriptif. Hasil analisis data rata-rata nilai keterampilan menulis deskripsi pra siklus yaitu sebesar 73,8 dengan ketuntasan klasikal 10\% dan rata-rata nilai keterampilan menulis teks deskripsi pada siklus I yaitu sebesar 89,5 dengan ketuntasan klasikal 93\%. Dari data hasil belajar tersebut dapat dikatakan bahwa hasil belajar keterampilan menulis teks deskripsi pada pra siklus ke siklus I mengalami peningkatan sebesar $83 \%$. Berdasarkan hasil analisis data dan pembahasan dapat disimpulkan bahwa hasil belajar keterampilan menulis teks deskripsi meningkat melalui penerapan strategi PLEASE berbantuan metode outdoor activity pada siswa kelas VIII A 1 SMP Negeri 1 Singaraja. Disarankan kepada guru bahasa Inggris untuk mengaplikasikan strategi PLEASE berbantuan metode outdoor activity karena dapat meningkatkan hasil keterampilan menulis teks deskripsi.
\end{abstract}

Keywords:

strategi PLEASE, outdoor activity, deskripsi

\section{PENDAHULUAN}

Menulis merupakan upaya mengekspresikan yang dilihat, dialami, dirasakan, dan dipikirkan ke dalam bahasa tulis, informasi-informasi dan ide-ide tersebut dituangkan dalam bentuk tulisan (Sriani, 2015). Menulis adalah kegiatan melahirkan pikiran dan perasaan dengan tulisan. Menurut Astuti (2014) dan Sulistyorini (2010) mengemukakan menulis adalah pemberian alam atau bakat alamiah, padahal menulis sebenarnya adalah keterampilan yang bisa dipelajari seperti halnya mengemudi, memasak, mengetik, dan lain sebagainya Menulis juga dapat diartikan dengan kegiaatn menuangkan ide, gagasan, pikiran, dan perasaan yang akan disampaikan kepada orang lain (pembaca) melalui media bahasa tulis untuk dipahami tepatbseperti yang dimaksud oleh penulis. Standar kompetensi menulis kelas VIII semester I adalah menyusun teks transaksional lisan dan tulis terkait keberadaan benda, orang, binatang. Kompetensi ini merujuk kepada penulisan teks deskripsi. Pada era globalisasi yang serba modern ini, keterampilan menulis dapat meningkatkan taraf hidup. Oleh karena itu, perlu dilakukan pembinaan yang intensif terhadap kemampuan menulis dengan tidak mengabaikan aspek bahasa yang lain (Godvany, 2017)

Keterampilan menulis memunculkan pengorganisasian ide dan pengorganisasian struktur sistematis yang berkaitan dengan tema tertentu. Secara umum, pengajaran keterampilan menulis dalam bahasa Inggris hanya menitik beratkan pada teknik dan metode tradisional yang kebanyakan berfokus 
pada penggunaan unsur - unsur kebahasaan seperti tata bahasa (grammar) saja, selain dari hal yang disebutkan barusan permasalahan pokok yang dihadapi siswa dalam membuat suatu karangan teks adalah pengorganisasian ide yang kurang baik berkaitan dengan topik yang dipelajari, yang mana melalui topik tertentu, peserta didik diminta untuk menuangkan ide kedalam suatu bentuk karangan teks.

Ide yang tidak terorganisir dengan baik dapat membuat peserta kesulitan dalam membuat suatu karangan teks, Peserta didik merasa bahwa mereka tidak memliki ide, padahal sebenarnya kebanyakan dari peserta didik langsung menuangkan ide ide pokok dalam satu paragraph sehingga kebingungan untuk melanjutkan tulisan pada paragraph berikutnya. Seharusnya, dengan pengorganisasian ide yang baik peserta didik mampu memecah ide - ide pokok kedalam beberapa paragraf untuk kemudian dikembangkan menjadi paragraf.

Berdasarkan hasil observasi dan wawancara dengan guru bidang studi bahasa Inggris yang mengajar di kelas VIII A1 SMP Negeri 1 Singaraja diperoleh informasi bahwa siswa masih mengalami kesulitan dalam menulis teks deskripsi. Tingginya nilai KKM (Ketuntasan Kriteria Minimal) yaitu 80 menjadi tolak ukur untuk siswa lebih meningkatkan kemampuan menulis. Adapun kesulitan siswa menulis teks deskripsi antara lain kesulitan menuangkan ide, pikiran dan gagasannya kedalam tulisan deskripsi. Kurangnya partisipasi peserta didik dalam mengikuti pembelajaran menulis khususnya menulis deskripsi juga menjadi kendala dikarenakan kurangnya metode, strategi ataupun pendekatan tertentu dalam mengajar menulis deskripsi .

Menurut Wellenreuther (1999) strategi pembelajaran PLEASE (Pick, Evaluate, Activate, Supply, End) berbantuan metode outdoor activity dapat digunakan dalam menulis teks deskripsi. Strategi dan metode ini diharapkan dapat membantu peserta didik dalam pembelajaran menulis deskripsi. Dengan menggunakan strategi PLEASE diharapkan dapat membantu siswa dalam mengembangkan ide, pikiran, maupun gagasan yang akan dituangkan kedalam tulisan deskripsi.Metode outdoor activity diharapkan dapat merangsang sudut pandang siswa terkait keberadaan benda yang ada disekitar. Selain itu, proses belajar mengajar akan terasa lebih hidup dan lebih menyenangkan dibandingkan hanya di dalam kelas.

Menurut Ratnimingsih (2004) dan Carrier (2009) menyatakan bahwa strategi PLEASE dalah singkatan dari Pick, List, Evaluate, Activate, Supply, End. Pick yang berarti pick your topic; siswa diminta untuk meilih topik yang ingin dikembangkan. List yang berarti list your ideas about the topic; siswa diminta untuk menuliskan ide-ide yang berhubungan denga topik yang diambil. Evaluate yang berarti evaluate the list; siswa mengevaluasi ide-ide yang mereka buat dengan memastikan susunan ide yang logis untuk mendukung kalimat utama. Activate yang berarti activate the paragaph with topic sentence; mengembangkan ide pokok menjadi kalimat utama. Supply yang berarti supply supporting sentences; siswa menjelaskan kalimat utama dengan menggunakan urutan ide logis sebelumnya dan menghubungkan dengan kalimat-kalimat pendukung/penjelas dengan logis. Terkahir adalah End yang berarti end with a concluding sentence and evaluate work.

Menurut Sadiman (1996:47) sebagai upaya untuk menciptakan kondisi yang kondusif untuk berlangsungnya kegiatan belajar mengajar dibutuhka ruang kelas yang nyama untuk peserta didik. Pembelajaran yang dilakukan di dalam ruang kelas mempunyai kelebihan yaitu, peserta didik lebh memperhatikan saat guru mengajar, suasana di dalam ruang kelas lebih tenang sehingga mendukung proses pembelajaran,dan guru juga lebih mudah dalam mengawasi tingkah laku peserta didik selama proses belajar mengajar berlangsung.

Penelitian dengan model yang sama pada penelitian terdahulu yaitu hasil penelitian yang dilakukan oleh Prasetyo (2014) dengan judul "Peningkatan Kemampuan Menulis Teks Deskripsi Ekspositoris Menggunakan Metode Outdoor activity pada Siswa Kelas X Akuntasi SMK Muhammadiyah 2 Wonosobo" dengan perolehan hasilnya sebagai berikut. Siswa kelas kelas X Akuntasi SMK Muhammadiyah 2 Wonosobo mampu menyusun teks deskripsi ekspositoris dengan menggunakan metode Outdoor activity. Hasil ini dibuktikan dari nilai rata-rata pretesnya yaitu 65,77 sedangkan nilai rata-rata post test siklus I adalah 77,66. Nilai rata-rata post test pada siklus II adalah 79,22. Dapat disimpulkan kemampuan siswa kelas kelas X Akuntasi SMK Muhammadiyah 2 Wonosobo dalam menyusun teks deskripsi menggunakan metode outdoor activity mengalami peningkatan. Sehubungan dengan hasil penelitian tersebut maka peneliti mengembangkan penelitian dalam pembelajaran Bahasa Inggris dengan menerapkan strategi PLEASE berbantuan metode outdoor activity agar dapat meningkatkan kompetensi menulis. Asiah (2014) menyatakan metode outdoor activty merupakan suatu kegiatan menyampaikan pelajaran di luar kelas, sehingga kegiatan atau aktivitas belajar - mengajar berlangsung di luar kelas atau di alam bebas. Kelebihan outdoor study ada enam, yakni (1) meningkatkan kapasitas belajar siswa, (2) mengungkap fakta dan memperoleh data di lapangan, (3) mendorong motivasi belajar siswa, (4) mengembangkan kemampuan fisik-sosial, (5) menjadikan belajar siswa bermakna, dan (6) metode cocok diterapkan pada mata pelajaran Geografi (Sudjana \& Rivai, 2010; Sumarmi, 2012; Vera, 2012). Metode outdoor study selain 
mempunyai kelebihan juga terdapat kekurangan. Sejati (2016) mengatakan kekurangan metode outdoor study salah satunya ialah guru repot mengatur/mengelola pembelajaran ketika di lapangan dan membutuhkan biaya perjalanan

Namun penelitian yang akan peneliti lakukan memiliki nuansa yang berbeda dengan penelitian penelitian sebelumnya. Perbedaannya terlihat pada subjek penelitian, objek penelitian, lokasi penelitian dan mata pelajaran yang diampuh. Subjek penelitian pada penelitian ini adalah penulis, objek penelitian ada siswa - siswi SMPN 1 Singaraja, lokasi penelitian adalah SMPN 1 Singaraja dan mata pelajaran yang diampuh adalah Bahasa Inggris.

Dipilihnya SMPN 1 Singaraja sebagai tempat penelitian karena disamping nilai menulis rendah, disekolah tersebut belum pernah menerapkan strategi PLEASE dan metode outdoor activity dalam pembelajaran menulis. Atas dasar itulah sangat diyakini bahwa penelitian dengan judul Penerapan Startegi PLEASE Berbantuan Metode Outdoor activity untuk Meningkatkan Kemampuan Menulis Teks Deskripsi pada Siswa kelas VIII A1 SMP Negeri 1 Singaraja penting dilakukan, guna melengkapi sisi lain dari penelitian - penelitian yang sudah ada dan meningkatkan kompetensi menulis siswa.

\section{METODE PENELITIAN}

Desain penelitian ini adalah penelitian tindakan kelas (PTK), yaitu pencermataan terhadap kegiatan berupa sebuah tindakan, yang sengaja dimunculkan dan terjadi dalam sebuah kelas secara bersama (Arikunto , 2010:4). Penelitian tindakan kelas biasanya dilakukan dengan beberapa siklus sampai memeroleh hasil yang diharapkan. Kegiatan setiap meliputi refleksi awal, perencanaan tindakan, pelaksanaan tindakan, observasi/evaluasi, dan refleksi (Wendra, 2010:53) Penelitian ini mengikuti tahaptahap penelitian tindakan kelas yang masing-masing siklus terdiri atas empat tahap yaitu: (1) perencanaan tindakan, (2) pelaksanaan tindakan, (3) observasi atau evaluasi, serta (4) refleksi. Latar dalam penelitian ini merujuk pada tempat dan waktu dilaksanakannya penelitian. Penelitian ini dilaksanakan di SMA Negeri 1 Singaraja. Subjek dalam penelitian ini adalah siswa kelas X MIPA 5 SMAN 1 Singaraja. Objek dalam penelitian ini adalah peningkatan kemampuan menulis siswa kelas X MIPA 5 SMA Negeri 1 Singaraja dengan metode mind mapping.

Data yang diperlukan untuk menjawab permasalahan yang ingin dipecahkan ialah (1) data mengenai kemampuan menulis siswa, (2) data mengenai respons siswa terhadap pembelajaran yang telah dilakukan. Untuk mengumpulkan data-data tersebut, peneliti menggunakan empat metode, yaitu metode observasi, metode tes, metode angket, dan metode wawancara. Analisis data yang digunakan dalam penelitian ini adalah analisis deskriptif kualitatif dan deskriptif kuantitatif. Ada tiga data yang harus dianalisis dalam penelitian ini. (1) Data mengenai kemampuan menulis siswa yang diperoleh melalui metode tes dianalisis secara deskriptif kuantitatif, (3) Data mengenai respons siswa yang diperoleh melalui metode angket dan wawancara dianalisis secara kuantitatif dan kualitatif.

Kriteria keberhasilan hasil belajar kemampuan menulis siswa ditunjukkan dengan adanya adanya ketuntasan klasikal kelas $\geq 80 \%$ dari 30 peserta didik. Kedua, kriteria respons siswa ditunjukkan oleh perolehan persentase $\geq 80 \%$ dari 30 peserta didik merespons positif dengan penerapan strategi PLEASE berbantuan metode outdoor activity yang digunakan.

\section{ANALISIS DAN PEMBAHASAN}

Langkah -langkah pembelajaran menulis teks deskripsi mengenai keberadaan benda dengan menggunakan stratgei PLEASE berbantuan metode Outdoor activity antara lain : Pengambilan data penelitian untuk pertama kalinya dilakukan pada Senin 9 Oktober 2017. Pada pertemuan ini materi yang diajarkan adalah menganalisis struktur teks deskripsi berdasarkan struktur dan ciri ahasaannya, guru menjelaskan strategi PLEASE kepada siswa dan membagikan contoh kerangka teks deskripsi dengan menggunakan strategi PLEASE. Guru pun menerangkan bagaimana menuliskan ide-ide menulis teks deskripsi yang dimulai dari Predict, List the ideas, Evaluate the ideas, Activate the paragraph with topic sentence, Supporting Sentence ,dan yang terakhir End with a concluding sentence and evaluate the work., mengajak siswa belajar diluar kelas yaitu di aula kemudian menuju ke halaman depan sekolah yang dijadikan topik menulis teks deskripsi.

Pertemuan kedua dilaksanakan pada tanggal 10 Oktober 2017 pada pukul 10.40-12.00 WITA. Penelitian ini dilaksanakan dalam satu siklus. Setiap siklusnya menggunakan empat tahap, yakni perencanaan, pelaksanaan, observasi, dan refleksi Penelitian ini diawali dengan tes awal (pra siklus) dan wawancara terhadap siswa. Pra -siklus menunjukkan nilai rata-rata yang diperoleh siswa sebesar 73,8 . Dengan KKM sebesar 80, hanya 3 siswa yang lulus KKM dan .27 siswa tidak lulus KKM. 
Siklus I dilaksanakan dalam dua kali pertemuan. Pertemuan pertama dilaksanakan pada 09 Oktober 2017 dan pertemuan kedua dilaksanakan pada 10 Oktober 2017. Siklus I menunjukkan nilai ratarata yang diperoleh siswa sebesar 89,5. Dengan KKM sebesar 80, ada 28 siswa yang lulus KKM dan 2 siswa tidak lulus KKM. Dengan jumlah tersebut, dapat dipersentasikan bahwa ketuntasann klasikal sebesar 93 \%. Persentasi ketuntasan klasikal ini menunjukkan bahwa penelitian ini sudah melampaui yang diharapkan, yakni 80\%. Dengan kata lain, siklus I ini telah berhasil.

Berdasarkan hasil observasi dari observer, pelaksanaan pembelajaran telah dilakukan oleh guru dengan sistematis dan semua langkah pembelajaran telah dilakukan. Selain itu, tidak ditemukan hal-hal yang perlu diperbaiki pada saat pelaksanaan pembelajaran. Respons siswa terhadap pembelajaran pada siklus I ini meningkat. Pada siklus I nilai rata-rata respons siswa sebesar 32,8 siswa menganggap pembelajaran positif. Respons siswa ini masih dalam kategori sangat baik. Dengan kata lain, pembelajaran yang dilakukan oleh guru sangat baik. Siklus I ini dinyatakan telah berhasil berdasarkan ketuntasan klasikal. Namun, secara individu, masih ada dua siswa yang belum dinyatakan berhasil. Walaupun kedua siswa ini belum berhasil, mereka telah menunjukkan peningkatan dalam pembelajaran jika dilihat dari nilai yang mereka peroleh pada pra siklus dan siklus I. Selain hal yang telah dipaparkan di atas, hasil siklus I berdasarkan angket yang diisi oleh siswa terkhusus pada poin kelemahan yang dihadapi siswa saat pembelajaran, masih diperoleh masalah yang dihadapi oleh siswa saat pembelajaran. Masalah yang mereka tuliskan hampir mirip dengan masalah yang mereka sebutkan pada pra siklus, yakni 1) siswa kesulitan dalam mengembangkan ide pokok paragraph, 2) siswa kesulitan dalam menentukan struktur teks, 3) siswa kesulitan dalam merangkai kalimat efektif dalam sebuah paragraph, 4)siswa kesulitan dalam menentukan pilihan kata 5) siswa kesulitan dalam menggunakan ejaan yang tepat yaitu tanda koma dan tanda titik.

Namun, beberapa siswa menulis tidak ada masalah. Ini menunjukkan bahwa sebagian hasil belajarnya dan responsnya yang mengatakan tidak ada masalah pada saat pembelajaran. Hal-hal yang paparkan di atas adalah seputar hasil penelitian ini dan korelasinya dengan hasil angket dan hasil observasi oleh observer. Secara ringkas peningkatan besar siswa sudah memahami penulisan teks deskripsi ini dengan baik. Terlihat dari hasil belajar menulis teks deskripsi siswa kelas VIII A1 SMP Negeri 1 Singaraja dapat dilihat pada tabel di bawah ini.

Tabel 1. Perbandingan Hasil Belajar Menulis Teks Deskripsi Pra-Siklus dan Siklus I.

\begin{tabular}{crr}
\hline Aspek yang dibandingkan & Pra-siklus & Siklus I \\
\hline Nilai rata-rata & 73,8 & 89,5 \\
Ketuntasan & & $93 \%$ \\
Klasikal & $10 \%$ & \\
\hline
\end{tabular}

Berdasarkan hasil perbandingan diatas dapat diketahui bahwa hasil belajar siswa mengalami peningkatan yang cukup signifikan. Hal ini dikarenakan kendala siswa yang paling umum adalah siswa kesulitan dalam mengorganisasikan ide-ide mereka menjadi sebuah karangan deskripsi yang utuh. Strategi PLEASE membantu siswa dalam mngorganisisakan ide-ide untuk menulis teks deskripsi dan mengembangkan ide-ide pokok tersebut ke dalam kalimat pendukung. Dengan menggunakan tahapantahapan didalam strategi PLEASE siswa lebih mudah menulis teks deskripsi dan berbantuan metode ourdoor activity, siswa dapat dengan leluasa menjelaskan keberadaan sesuai dengan sudut pandang mereka dan disesuaikan dengan kerangka karangan yang mereka tulis di strategi PLEASE. Hal ini sejalan dengan penelitian oleh Nelia (2014) yang menunjukkan bahwa bahwa metode outdoor study dapat meningkatkan kemampuan menulis karangan deskripsi pada pembelajaran bahasa Indonesia siswa kelas IV SDN 36 Pontianak Selatan. Menurut Brown (2012) pembelajaran outdoor dapat menjadikan siswa lebih paham tentang konsep lokasi termasuk fenomena fisik dan kegiatan manusia di tempat yang mereka kunjungi.

Berdasarkan hasil penelitian yang telah peneliti lakukan serta teori-teori pendukung hasil penelitian yang telah dipaparkan di atas, dapat disimpulkan bahwa Penerapan strategi PLEAE (Pick, List, Evaluate, Activate, End) berbantuan metode outdoor activity dapat meningkatkan kemampuan menulis teks deskripsi pada siswakelas VIII-A1 SMP Negeri 1 Singaraja. 


\section{KESIMPULAN}

Berdasarkan hasil dan pembahasan penelitian tindakan kelas tehadap proses pembelajaran untuk meningkatkan kemampuan menulis teks deskripsi dan mengembangkan ide menggunakan strategi PLEASE berbantuan metode outdoor activity pada kelas VIII A1 SMP Negeri 1 Singaraja dapat disimpulkan sebagai berikut. Terjadi peningkatan keterampilan menulis teks deskripsi menggunakan strategi PLEASE berbantuan metode outdoor activity pada kelas VIII A1 SMP Negeri 1 Singaraja Hal itu terlihat dari peningkatan nilai rata-rata yang diperoleh siswa pada pra siklus adalah 78,9 dengan jumlah siswa yang lulus KKM adalah siswa dan pada siklus II meningkat menjadi 89,5 dengan jumlah siswa yang lulus KKM adalah 28 siswa dari jumlah total 30 siswa.

Adapun kesulitan yang dialami siswa pada siklus siswa mengalami penurunan. Kesulitan tersebut akhirnya dapat diatasi seperti: 1) siswa lebih mampu mengatasi kesulitan dalam mengembangkan ide pokok paragraf, 2) siswa lebih mampu mengatasi kesulitan dalam merangkai kalimat efektif dalam sebuah paragraf, 3) siswa lebih mampu mengatasi kesulitan dalam merangkai kalimat efektif dalam menentukan pilihan kata 4)siswa lebih mampu mengatasi kesulitan dalam menggunakan ejaan yang tepat yaitu tanda koma dan tanda titik.

\section{DAFTAR PUSTAKA}

AEKOP, ATMOJO. 2016Pick, List, Evaluate, Activate, Supply, End (PLEASE) Strategy: Teaching Writing Viewed from Students' Self-Esteem (An Experimental Research at the Tenth Grade of SMAN 1 Tangen in the Academic Year of 2016/2017). Journal Online.

Asiah, Siti. 2014. Penerapan Metode Out Door Activity Dalam Pembelajaran Ipa Untuk Meningkatkan Hasil Belajar Siswa Sekolah Dasar. JPGSD.Volume 02 Nomor 03

Astuti, Yanuarita Widi dan Ali Mustadi. 2014. Pengaruh Penggunaan Media Film Animasi Terhadap Keterampilan Menulis Karangan Narasi Siswa Kelas V SD. Yogyakarta : Jurnal Prima Edukasia. Vol. 2 No 2.

Arikunto, S., Dkk., 2008. penelitian tindakan kelas. Jakarta: PT Bumi Aksara.

Brown, Mike. 2012. Developing a Place-based Approach to Outdoor Education in Aotearoa New Zealand. Teaching and Learning Reseacrh Initiative Summary: 1-7.

Carrier, S. J. 2009. The Effect of Outdoor Science Lesson with Elementary School Students on Preservice Teacher's Self-Eficacy. Journal of Elementary Science Education, Vol. 21, No. 2.

Godvany, Nilla, I Gede Nurjaya, Gede Gunatama. 2017. Meningkatkan Keterampilan Menulis Karangan Deskripsi Melalui Kegiatan Belajar Di Luar Kelas Dengan Pendekatan Kontekstual Pada Siswa Kelas Vii Smp Negeri 1 Sukasada. e-Journal Universitas Pendidikan Ganesha Jurusan Pendidikan Bahasa dan Sastra Indonesia, Volume 6 No. 1

Jauhari, Heri. 2013. Terampil Mengarang. Bandung: Nuansa Cendikia

Keraf, Gorys. 1995. Eksposisi dan Deskripsi. Ende Flores: Nusa Indah

Kuncoro, Mudrajad. 2009. Mahir Menulis. Jakarta: Erlangga.

Nelia, Dominika Fitri, Kaswari, Sugiono. 2014. Peningkatan Kemampuan Menulis Karangan Deskripsi Dengan Menggunakan Metode Outdoor Study Di Sekolah Dasar. Jurnal Pendidikan dan Pembelajaran Volume 3 Nomor 8.

Ratminingsih, Ni Made,2014. Teaching English as Foreign Laguage 1.Singaraja: Undiksha PRESS.

Sejati, Andri Estining, Sumarmi, I Nyoman Ruja. 2016. Pengaruh Metode Pembelajaran Outdoor Study Terhadap Kemampuan Menulis Karya Ilmiah Geografi Sma . Jurnal Pendidikan: Teori, Penelitian, dan Pengembangan Volume 1 Nomor 2 Halaman: 80-86 
Sriani,Ni Ketut, I Made Sutama, Ida Ayu Made Darmayanti. 2015. Penerapan Model Pembelajaran Experiential Learning Untuk Meningkatkan Kemampuan Menulis Paragraf Deskripsi Pada Siswa Kelas VII B SMP Negeri 2 Tampaksiring. E-Journal Undiksha. Vol. 3 No 1.

Sudjana \& Rivai. 2010. Media Pengajaran. Bandung: Sinar Baru Algesindo

Sulistyorini, Dwi. 2010. Peningkatan Keterampilan Menulis Puisi Dengan Media Gambar Pada Siswa Kelas V SDN Sawojajar V Kota Malang. J-TEQIP. Vol. 1 No 1.

Sumarmi. 2012. Model-Model Pembelajaran Geografi. Malang: Aditya Media Publishing

Vera, Adelia. 2012. Metode Mengajar Anak di Luar Ruang Kelas (outdoor study). Yogyakarta : Media Wacana Press

Vereecke, A.and Muylle, S. (2006) performance improvement through supply chain collaboration in Europe International Journal of operations \& production management, Vol. 26, No.11.

Wellenreuther, M. (1999). Warum eigentlich Alaska?! Kritische Anmerkungen zur Evaluationsstudie von Klawe \& Bräuer "Erlebnispädagogik zwischen Alltag und Alaska". Zeitschrift für Erlebnispädagogik, Vol. 4, No. 29. 